\title{
The Relationship of House Environmental Sanitation with Infection of Muhamadiyah Elementry School Students in Deli Serdang District
}

\author{
Salbiah $^{1 *}$, Lestari Rahmah ${ }^{2}$, Tri Prasetyorini ${ }^{1}$ \\ ${ }^{1}$ Health Polytechnic Jakarta III \\ Indonesia \\ ${ }^{2}$ Head of Health Polytechnic Medan \\ Jl. Arteri JORR, Jatiwarna, Bekasi, INDONESIA \\ *Corresponding author's email: salbiah.khamaruddin80 [AT] gmail.com
}

\begin{abstract}
-
Background: The case of helminthiasis in elementary school children in Indonesia is still quite high at 28\%. This worm disease is caused by the Soil Transmited Helminths (STH) group. This group of worms is transmitted by means of land. The environment contaminated by worm eggs increases the incidence of helminthiasis in children.
\end{abstract}

Objective: To analyze the relationship between home environmental sanitation and helminthiasis in elementary school students in Deli Serdang Regency.

Method: This study was analytical with cross-sectional data analysis. The population of this study were all Muhammadiyah 37 Tanjung Selamat Elementary School students with a sample of 58 people. The research data was obtained from questionnaires, observations, and faecal examination in the laboratory with the method of using a 1 $2 \%$ eosin method.

Results and Discussion: Based on the results of the questionnaire and observation, it was found that $34.5 \%$ of children lived in a home environment that did not comply health requirements. Laboratory results showed that $15.5 \%$ of children were infected by the Soil Transmitted Helminths. The results of the statistical test showed a significant relationship between environmental sanitation and STH infection in elementary school students in Deli Serdang District with p-value $=0.003$ (p-value $<0.005)$.

Conclusions and suggestions: There is a relationship between environmental sanitation and helminthiasis in elementary school students in Deli Serdang Regency. It is recommended to the school to always provide understanding to children about the importance of maintaining cleanliness of the school environment and also reactivating the School Health Unit program and enforcing discipline and providing guidance for children who lack hygiene such as cutting long nails as a discipline to hygiene child.

Keywords - Home Environmental Sanitation, Soil Transmited Helminths, elementary school students

\section{INTRODUCTION}

Worm disease is still common in all parts of Indonesia. The disease caused by helminth infections is classified as a disease that does not receive enough attention, because it is still often regarded as a disease that does not cause plague or death. However, helminthiasis is actually enough to make the patients suffer losses, because slowly the existence of worm infestations in the patient's body will cause health problems ranging from mild, moderate to severe which are shown as clinical manifestations including reduced appetite, discomfort in the stomach, hives, allergies, anemia, malnutrition, pneumonitis, Loeffler's syndrome and others. Worm disease is often associated with the patient's environmental conditions, patient's socioeconomic condition and patient's education level. One of the helminthiasis that still happens to many people in Indonesia is caused by the Soil Transmitted Helminth group [1].

The Soil Transmitted Helminth is an intestinal nematode in which its transmission or life cycle passes through the soil. Intestinal nematodes belonging to the Soil Transmitted Helminth are roundworms (Ascaris lumbricoides), whipworms (Trichuris trichiura), Strongyloides stercoralis and Hookworms (Necator americanus and Ancylostoma dudenale) [2]. 
The problem of helminthiasis in Indonesia is very closely related to climate and personal hygiene, homes and the surrounding environment as well as high population density. During the rainy season, humid air, houses with dirt floors, poor health sanitation knowledge is a factor in the high incidence of helminthiasis. In accordance with research conducted by Andaruni which shows that the factors causing worm infections include personal hygiene factors, including washing hands, cutting and cleaning nails, use of footwear, and environmental sanitation factors, including water sources, human waste disposal and food sanitation [3].

The prevalence of intestinal worms is generally still very high. Based on WHO, more than 1.5 billion people or $24 \%$ of the world's population were infected by Soil Transmitted Helminth. Most of these parasitic infections attack schoolage children. More than 270 million pre-school-aged children and 600 million school-age children live in this vulnerable area infected with the parasite [4]. In Indonesia, the prevalence of helminthiasis in 2015 was still very high at 28\% [5].

The high prevalence of helminthiasis is caused by many factors that influence the life cycle of this worm, namely inadequate environmental sanitation conditions, poor personal hygiene behavior, and the socioeconomic conditions of the demographic areas around.

Earthworm infections are transmitted because they are influenced by environmental factors, poor environmental sanitation [3], including water source sanitation, human waste disposal, food sanitation [3].

Soil Transmitted Helminth generally infects poor people with poor sanitation. Worms is one of the diseases that is still a health problem in Indonesia, which is transmitted through the soil, and can cause a decrease in health, nutrition, intelligence and productivity of sufferers so that economically many cause losses. Worms cause loss of carbohydrates and protein and blood loss, thereby reducing the quality of human resources. Considering that intestinal worms are an environment-based disease, attention to environmental sanitation needs to be increased [6].

Environmental health is essentially an optimum environmental condition or condition so that it positively influences the realization of optimal health status as well. The scope of environmental health includes, among others: housing, disposal of human waste (feces), the provision of clean water, garbage disposal, disposal of dirty water (waste water), livestock houses (cages) and so on. As for what is meant by environmental health efforts is an effort to improve or optimize the human environment so that it is a good medium for the realization of optimum health for humans who live in it [7].

From the results of a preliminary survey conducted by the author, there are many puddles and soil conditions that are always wet and humid because the school is under construction and building repairs.

Based on the above description, the author wants to examine how the picture of environmental sanitation and helminthiasis on elementary school students in Deli Serdang Regency.

The purpose of this study was to determine the relationship between environmental sanitation at home with worm infections in elementary school students in Deli Serdang Regency.

\section{RESEARCH METHODS}

This type of research is analytic research with cross sectional design to see the relationship between environmental sanitation with helminthiasis infection. The study was conducted at Deli Serdang Regency elementary school. Worm infestation is carried out in the Integrated Health Polytechnic Laboratory of the Ministry of Health, Medan. The study was conducted in March - June 2018. The research sample was taken using the formula Lameshow et al (1997) totaling 55 students. The sampling technique uses a simple random sampling technique.

The data used are primary data obtained through laboratory and questionnaire examinations and secondary data, namely absenteeism and elementary school student data in Deli Serdang Regency. Data collection is carried out by: (1) Laboratory examination to determine helminthiasis infections, (2) Filling out questionnaires with observation of home environmental sanitation.

The inspection method used is a direct examination method (native method) using eosin $2 \%$. The use of eosin is to more clearly distinguish worm eggs from the surrounding impurities [8].

To test the hypothesis in this study conducted with the chi-square / chi-square test, this method is used to determine the relationship of all independent variables (independent variables) to the dependent variable (dependent variable) that can be done at once. Using the degree of significance with alpha $=0.005$ degrees of confidence $95 \%$ ). If the value of $\mathrm{p}$ $<0.005$, the statistical results are said to be significant / related. 


\section{RESEARCH RESULTS}

Table 1. Observation Results of Respondent's Home Environments

\begin{tabular}{|c|c|c|c|c|c|c|}
\hline \multirow{3}{*}{ Home environment } & \multicolumn{4}{|c|}{ Observation result } & \multirow{2}{*}{\multicolumn{2}{|c|}{ Total }} \\
\hline & \multicolumn{2}{|c|}{ Available } & \multicolumn{2}{|c|}{ Not Available } & & \\
\hline & $\mathbf{N}$ & $\%$ & $\mathbf{N}$ & $\%$ & $\mathbf{n}$ & $\%$ \\
\hline Clean water sources & 57 & 98,3 & 1 & 1,7 & 58 & 100 \\
\hline Have a toilet at home & 58 & 100 & 0 & 0 & 58 & 100 \\
\hline Clean water is available in the toilet & 58 & 100 & 0 & 0 & 58 & 100 \\
\hline Soap is available in the toilet & 58 & 100 & 0 & 0 & 58 & 100 \\
\hline Waste disposal facilities is available & 39 & 67,2 & 19 & 32,8 & 58 & 100 \\
\hline $\begin{array}{l}\text { Waste water disposal facilities is } \\
\text { available }\end{array}$ & 51 & 87,9 & 7 & 12,1 & 58 & 100 \\
\hline
\end{tabular}

Based on data from table 1 it can be seen that there is 1 house $(1.7 \%)$ that does not have a clean water source. 19 houses $(32.8 \%)$ out of 58 respondent's homes did not have waste disposal facilities and 7 houses $(12.1 \%)$ did not have waste water disposal facilities.

Table 2. Distribution of Respondent Frequencies Based on Sanitation Respondent's Homes

\begin{tabular}{cccc}
\hline No & Sanitation Respondent's Homes & $\begin{array}{c}\text { Total } \\
(\mathbf{n})\end{array}$ & $\begin{array}{c}\text { Percentage } \\
(\boldsymbol{\%})\end{array}$ \\
\hline 1 & Comply the health requirement & 38 & 65,5 \\
2 & Did not comply the health requirement & 20 & 34,5 \\
\hline & Total & $\mathbf{5 8}$ & $\mathbf{1 0 0}$
\end{tabular}

From Table 2 it can be seen from 58 respondents, as many as 20 people (34.5\%) lived in homes that did not comply health requirements.

The results of research on STH infections in Muhammadiyah 37 Elementary School students in Deli Serdang Regency which were examined by laboratory faeces can be seen in the table below:

Table 3. Frequency Distribution of Respondent's helminthiasis

\begin{tabular}{cccc}
\hline No & Helminthiasis & Total (Children) & Percentage (\%) \\
\hline 1 & Positve & 9 & 15,5 \\
2 & Negative & 49 & 84,5 \\
\hline & Total & 58 & 100 \\
\hline
\end{tabular}

From Table 3 above it can be seen that the STH infections of Muhammadiyah 37 Elementary School students in Deli Serdangs Regency are 9 children $(15.5 \%)$ out of the 58 people examined.

Table 4. Positive Frequency Distribution of Worm Infection by Respondent Worm Type

\begin{tabular}{cccc}
\hline No & Types of worm & Total (Children) & Percentage (\%) \\
\hline 1 & Ascaris lumbricoides & 8 & 13,8 \\
2 & Trichuris trichiura & 1 & 1,7 \\
\hline & Total & 9 & 15,5 \\
\hline
\end{tabular}

From table 4 above it can be seen that as many as 9 children were infected with helminthiasis with details of $A$. lumbricoides worm infection of 8 children (13.8\%) and T. trichiura infection of 1 child (1.7\%).

Table 5. Distribution of Worm Infection Frequency by Respondent's Gender.

\begin{tabular}{cccc}
\hline No & Gender & Total (Children) & Percentage $(\boldsymbol{\%})$ \\
\hline 1 & Boy & 6 & 10,3 \\
2 & Girl & 3 & 5,2 \\
\hline & Total & 9 & 15,5 \\
\hline
\end{tabular}

From Table 5 above it can be seen that based on gender, the number of worm infections in boys is greater than 
infections in girls. 6 out of 36 boys are infected (10.3\%), and 3 out of 22 girls are infected (5.2\%).

Table 6. Relationship between Sanitation in the Home Environment and Respondent's Worm Infection

\begin{tabular}{|c|c|c|c|c|c|c|c|c|}
\hline \multirow{3}{*}{ No } & \multirow{3}{*}{ Sanitation in the Home Environment } & \multicolumn{4}{|c|}{ Helminthiasis } & \multirow{2}{*}{\multicolumn{2}{|c|}{ Total }} & \multirow{3}{*}{ p-value } \\
\hline & & \multicolumn{2}{|c|}{ Positive } & \multicolumn{2}{|c|}{ Negative } & & & \\
\hline & & $\mathrm{n}$ & $\%$ & $\mathrm{n}$ & $\%$ & $\mathrm{~N}$ & $\%$ & \\
\hline 1 & Comply the health requirement & 2 & 5,3 & 36 & 94,7 & 38 & 65,5 & \\
\hline \multirow[t]{2}{*}{2} & Did not comply the health requirement & 7 & 35 & 13 & 65 & 20 & 34,5 & 0,003 \\
\hline & Total & 9 & 15,5 & 49 & 84,5 & 58 & 100 & \\
\hline
\end{tabular}

Based on table 6 it can be showed that helminthiasis in children living in the home environment that have comply the health requirements of 2 children $(5.3 \%)$ and 7 children $(35 \%)$ infected with helminthiasis live in a home environment that have not comply health requirements. Chi-square test results showed a significant relationship between sanitation of the home environment with helminthiasis infection in elementary school students with a p-value $=0.003(<0.05)$.

\section{DISCUSSION}

Environmental factors influence the 'health-sick' problem or the health status of individuals and communities. Although there are other factors that influence such as behavior, health services, and heredity. In accordance with Hendrik L. Blum's theory which states that these four factors in addition to directly affecting health, also influence each other. Health status will be achieved optimally if the four factors together have optimal conditions. If one of the factors is in a disturbed state (not optimal), then the health status will be shifted below the optimal [7].

From the results of observations on the student's home environment, it was found that there was 1 house $(1.7 \%)$ that did not have clean water sources. 19 houses (32.8\%) out of 58 respondents' homes did not have waste disposal facilities and 7 houses $(12.1 \%$ ) did not have waste water disposal facilities. Based on several indicators of healthy and unhealthy houses released by the Department of Health, it can be said that as many as 20 people 9 (34.5\%) Muhamadiyah 37 Elementary School students in Deli Serdang Regency live in a home environment that does not comply health requirements.

Of the 58 people examined, $9(15.5 \%)$ were positive infected. 8 out of 9 children are infected with Ascaris lumbricoides. The high rate of A. lumbricoides infection is in line with the results of a study conducted by Chadijah et al in 2014 in elementary schools in the city of Palu stating that the most dominant type of worm infecting was $A$. lumbricoides (83.34\%) with a worm prevalence of 31, 6\% [9]. Research conducted by Kusmi et al in 2015 at SD N 29 Purus Padang also showed that the incidence of ascariasis was more dominant than the incidence of trichuriasis, in which of the total worm infections $38 \%, 33 \%$ were infections caused by A.lumbricoides [10].

The results showed that 20 children (34.5\%) lived in homes that did not meet health requirements. Chi-square test results on STH infection of the home environment obtained p-value $=0.003(<0.005)$ meaning that there is a significant relationship between sanitation of the home environment with helminthiasis infection.

Based on observations of the children's home environment, 1 house did not have a clean water source. In general, the source of water used in respondent's houses is dug well or drinking water company. All respondent houses have latrines and water and soap in the toilet.

The importance of waste disposal facilities and waste water disposal facilities in the home environment is still lacking attention. 19 children's homes $(32.8 \%)$ did not have waste disposal facilities, causing a lot of garbage to be scattered in the yard. 7 houses $(12.1 \%)$ did not provide waste water disposal facilities and resulted in the house yard always having standing water.

Sanitation in the home environment that does not meet health requirements has a significant relationship with helminthiasis.

\section{CONCLUSIONS}

The prevalence of helminthiasis in Muhammadiyah 37 Elementary School students in Deli Serdangs Regency by $15.5 \%$ is dominated by Ascaris lumbricoides. As many as $34.5 \%$ of children live in homes that do not compy health requirements. A total of $98.3 \%$ of children's homes have a source of clean water. $32.8 \%$ of children's homes do not have waste disposal facilities. $12.1 \%$ of children's homes do not provide facilities disposal of wastewater in the home environment. There is a meaningful relationship between sanitation in the home environment with STH infection in Muhammadiyah 37 Elementary School students in Deli Serdang Regency.

\section{SUGGESTION}

It is suggested to the school to always provide an understanding to children about the importance of maintaining personal hygiene and also reactivate the School Health Unit program and to enforce discipline and provide guidance for children who are less likely to maintain hygiene such as cutting long nails as a discipline of children's hygiene. 


\section{ACKNOWLEDGEMENT}

Ethical clearance for this study was granted by Health Polytechnic Ministry of Health Jakarta III.

\section{REFERENCES}

[1] Palgunadi, BU. Faktor-faktor Yang Mempengaruhi Kejadian Kecacingan Yang Disebabkan Oleh Soil Tranmitted Helminth Di Indonesia. FK Universitas Wijaya Kusuma. Surabaya. 2011.

[2] Prasetyo, H. Buku Ajar Parasitologi Kedokteran Parasit Usus. Sagung Seto. Dept. Parasitologi FK Universitas Airlangga. 2014.

[3] Andaruni, A; Fatimah, S; Simangunsong, B. Gambaran Faktor-faktor Penyebab Infeksi Cacingan Pada Anak Di SDN 01 Pasirlagu Cisarua. Fakultas Ilmu Keperawatan Universitas Padjajaran. Bandung. 2012

[4] WHO (World Health Organizations. Soil-transmitted helminth infections. Media centre. 2017. Available at http://www.who.int/mediacentre/factsheets/fs366/en/

[5] Agustina, D. Cacingan Bukan Lagi Penyakit Orang Kampung. CNN Indonesia. 5 November 2015 Available at http://m.cnnindonesia.com/gaya-hidup/20151105194633-255-89764/cacingan-bukan-lagi-penyakit-orang-kampung/

[6] Direktorat Jendral PP-PL. Pedoman Pengendalian Kecacingan. Buku Kementerian Kesehatan RI. Jakarta. 2012.

[7] Notoatmodjo. Kesehatan Masyarakat Ilmu dan Seni. Edisi Revisi 2011 Rineka Cipta. Jakarta. 2011.

[8] Setya, AK. Parasitologi Praktikum Analis Kesehatan. Penerbit Buku Kedokteran EGC. Jakarta. 2015.

[9] Chadijah S, Sumolang P, Veridiana N. 2014. Hubungan Pengetahuan, Perilaku dan Sanitasi Lingkungan dengan Angka Kecacingan Pada Anak Sekolah Dasar di Kota Palu. Media Litbangkes. 24(1) : 50-56.

[10] Kusmi H, Irawati N, Kadri H. 2015. Hubungan Sanitasi Lingkungan Rumah dengan Kejadian Askariasis dan Trikuriasis pada Siswa SDN 29 Purus Padang. Jurnal Kesehatan Andalas. 4(3) 